\title{
DRYING CHARACTERISTICS AND QUALITY CHANGES OF MORINGA LEAVES
}

\author{
Suliman, A. E. ${ }^{1}$, \\ Abdelhay, Y. B. ${ }^{2}$ and Saad, A. E. ${ }^{3}$ \\ ABSTRACT
}

The drying characteristics and quality changes of moringa oleifera leaves as a medicinal and aromatic plants were studied and investigated by using a laboratory dryer with initial moisture content of $86.7 \%$ (wet base). Three different drying air temperatures $\left(40,50\right.$ and $60{ }^{\circ} \mathrm{C}$ ) with three different drying air velocities $(0.45,1.0$ and $1.5 \mathrm{~m} / \mathrm{s})$ were functioned during this laboratory experiment. The quality of dried moringa leaves including protein, ascorbic acid (vitamin C), calcium and potassium were estimated. The experiment was carried out at Agricultural Engineering Department, Cairo University, Egypt in 2015.The obtained results demonstrated that the increase of drying temperature and air velocity resulted in lower moisture content and the drying rate was faster at the beginning than at the end for all treatments. At drying air temperature $60^{\circ} \mathrm{C}$ with air velocity $1.5 \mathrm{~m} / \mathrm{s}$ showed the best data, at which in dried moringa, the moisture content decreased to $9.35 \%$ within drying time 5.5 hours, the average drying rate was $14.06 \% / h$, drying ratio was $4.42: 1$ and the average evaporating rate was 28.13 $g_{\text {water }} /$. Also, the quality tests of dried moringa leaves showed that, the best quality in terms of higher retention of protein and potassium at air temperature $60^{\circ} \mathrm{C}$ with air velocity $1.5 \mathrm{~m} / \mathrm{s}$, while at air temperature $40^{\circ} \mathrm{C}$ with air velocity $0.45 \mathrm{~m} / \mathrm{s}$ showed the best quality in terms of higher retention of vitamin $C$ and calcium.

Keywords: Drying characteristics, Moringa leaves, Quality.

\section{INTRODUCTION}

The operation of drying in Egypt is done by using natural sun and
wind to dry medical and aromatic plants, but low quality and high
losses occur because during the drying process the aromatic plants are contaminated by dust, rain, birds and insects (Abdel-Galil and ElNakib 2008).

\footnotetext{
${ }^{1}$ Prof., Agric. Eng. Dept., Fac. Of Agric., Giza, Egypt.

${ }^{2}$ Assistant Prof., Agric. Eng. Dept., Fac. Of Agric., Cairo Univ., Giza, Egypt.

${ }^{3}$ Graduate Student of Agric. Eng. Dept., Fac. Of Agric., Cairo Univ., Giza, Egypt.
} 
Industrial drying maintains the oil percentage and components of aromatic plants. Medicinal plants have been used for different purposes in many regions of world since ancient times. After world health organizations (WHO), medicinal plants are commonly used in preventing and treating specific ailments and diseases and are generally considered to play a beneficial role in health care. Medicinal and aromatic plants possess several proteins, minerals constituting excellent dietary food. Some cultivars from medicinal plant families are also used as ingredients to season or to give a pleasant flavor or smell to foods. Therefore, the terms "medicinal" and "aromatic" are usually used in conjunction. These plants are used in medicinal and pharmaceutical purposes, food and food ingredients, herbal tea, cosmetics, perfumery, aromatherapy pest and disease control and plant growth regulators, (Öztekin and martinov 2007). Moringa oleifera is grown largely in tropical and sub-tropical areas, it can be described as miracle tree and its leaves are an abundant indigenous source of digestible proteins, vitamins and minerals that are necessary for human beings of all ages. It was estimated that almost three hundred diseases can be cured by taking moringa leaves along with hundreds of other health benefits. It also contains more than 90 nutrients, different antioxidants and all the eight essential amino acids, (Ali et al. 2014).

Ozguven and Tansi (1999) found that in trials on Marjoram (origanum marjoram) in Cukurova, Turkey, the highest fresh $(1077.2 \mathrm{~kg} / \mathrm{day})$ and dried herb yields (492.9 kg/day) and essential oil yield (77.7 litters/day) were obtained at the post flowering stage. The main components of the oil were gamma-terpinen, P-Cyomol and terpineol.

Kassem et al. (2006) studded the effect of solar energy and other drying methods on quality of some medicinal plants. The solar drying $\left(35^{\circ} \mathrm{C}\right)$, natural drying (sun drying $30^{\circ} \mathrm{C}$ ), and artificial drying (in oven at $45^{\circ} \mathrm{C}$ ) are the three different systems used for drying Lemongrass (cymbopogoncitrates), Oregano (Origanum vulgare), Spearmint (Menthavirdis) and Peppermint (Menthapepperita).

Arafa (2007) reported that the effect of drying air velocity on moisture content is not a pronounced when the air velocity increased from 1.1 to $2.0 \mathrm{~m} / \mathrm{s}$. 
Ali et al. (2014) studded that the drying kinetics of moringa oleifera leaves and found that The initial drying rate was very high at all drying temperatures because high heat was supplied at high temperature due to which more evaporation took place .The drying time for oven $50{ }^{\circ} \mathrm{C}$ and oven $60{ }^{\circ} \mathrm{C}$ up to the constant moisture reading could be shortened by $28.12 \%$ and $75 \%$ respectively when compared to oven at $40{ }^{\circ} \mathrm{C}$. The total time taken by moringa leaves to reach moisture contents of 4.77, 3.02 and $3.02 \%$ at temperatures of 40,50 and $60{ }^{\circ} \mathrm{C}$ were $8,5.75$ and $2 \mathrm{~h}$ respectively.The results further indicated that all three oven temperatures able to reduce moringa leaves temperature less than $5 \%$ that is favorable for further processing.

This research is aimed to investigate the drying characteristics and quality changes of moringa leaves by using different drying air temperatures and different air velocities.

\section{MATERIALS AND METHODS}

In the present investigation the artificial drying was done by using a laboratory drying prototype for drying moringa oleifera leaves. For artificial drying method, a laboratory drying prototype was used in drying experiment in laboratory of processing engineering, agricultural engineering department, faculty of agriculture, Cairo University.

Fresh moringa leaves were collected from moringa trees grown at agriculture farm of the Egyptian scientific association for moringa in Al Sharkia Governorate, Egypt. The initial moisture content of moringa leaves was $86.7 \%$ (wet base).

\section{Dryer specification and description:}

A laboratory drying prototype consists of air inlet, heating unit cylindrical drying chamber and air outlet as shown in fig. (1).

Air inlet: At the bottom of the dryer there is air inlet connected to air compressor with varies velocities and 400 watt of power to pull air from room into the dryer.

Heating unit: It consists of 4 electric heating elements which can use any one of them by a panel used to control the heating elements so after the air enter the dryer it passes through the heating unit to be heated then the heated airflow passes to the cylindrical chamber. 
Cylindrical drying chamber: It is found at the middle of a cylindrical duct connected to the heating unit. It has a drying tray which the product is placed and this tray made of a metal mesh to allow the heated airflow to pass through it with its affecting velocity and temperature required for the drying of the agricultural product. The drying tray is suspended inside the cylindrical drying chamber by means of four wires. These wires are connected to an electric balance fixed on a shelf above the cylindrical drying chamberwith accuracy $0.01 \mathrm{gm}$. These arrangements enable reading the weight of the drying tray with its load of product at any time during the drying process.

Air outlet: It is found above the drying chamber to allow the drying air to go out the drying chamber to the outside air.

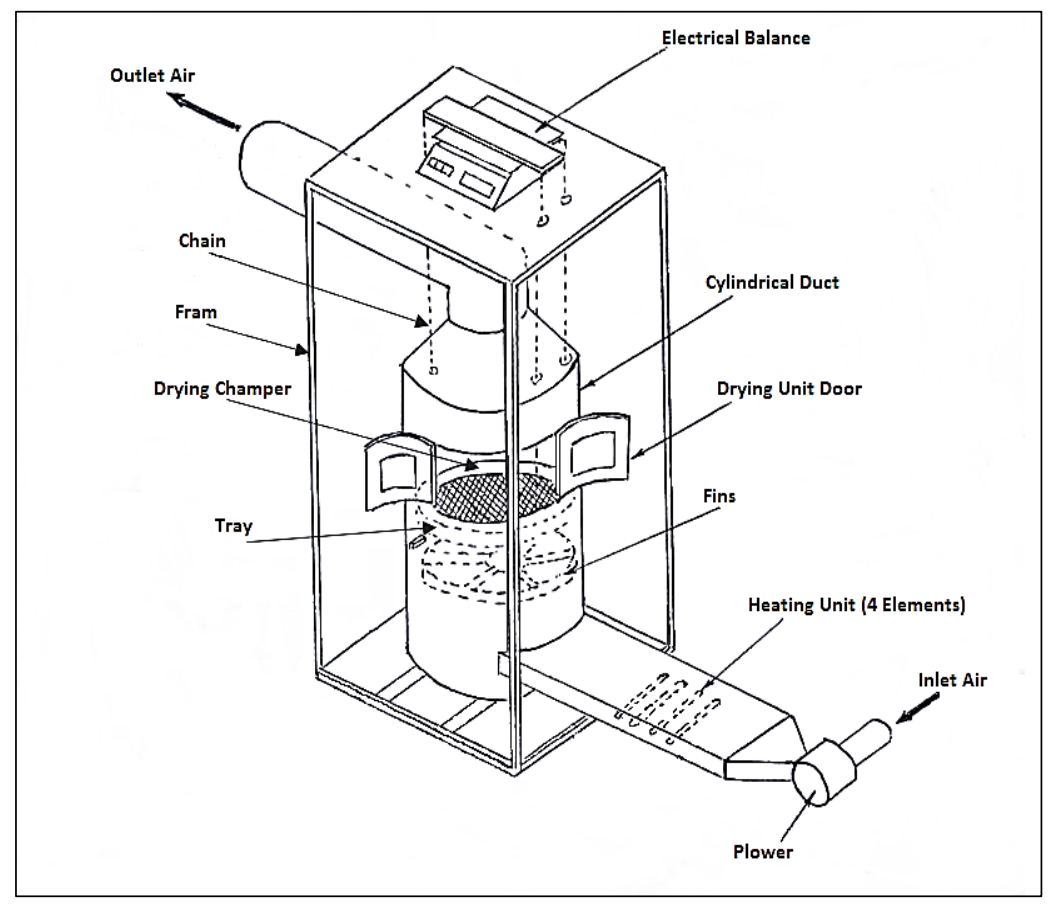

Fig. (1): Schematic diagram of the experimental dryer.

\section{Instrumentation:}

An anemometer model (sp-51) was used for measuring the air speed inside the air supply tube, ranging from 0 to $50 \mathrm{~m} / \mathrm{s}$. A 12 channel digital thermometer with thermocouples (type T) model T.M-201 was used to measure temperature, with a range of 0 to $100{ }^{\circ} \mathrm{C}$ and accuracy of 0.01 
${ }^{\circ} \mathrm{C}$. A digital balance with accuracy of $0.1 \mathrm{~g}$ was used, to measure the changes of samples mass (before and after drying).

\section{Experimental treatments:}

The following variables were tested to show their effects on moisture content, drying rate and drying ratio on moringa leaves:

1- Drying air temperature: three different levels of air drying temperature were functioned $\left(40,50\right.$ and $\left.60^{\circ} \mathrm{C}\right)$.

2- Air velocity: three different levels of air velocity were functioned $(0.45,1.0$ and $1.5 \mathrm{~m} / \mathrm{s})$.

\section{Experimental procedure:}

The samples of moringa leaves were washed to remove the dust before entering into the drying unit. The initial moisture content was determined by standard oven method (drying the sample of $50 \mathrm{~g}$ at $105^{\circ} \mathrm{C}$ for $24 \mathrm{~h}$.). Before the start of the drying test, the dryer was allowed to run for $30 \mathrm{~min}$ using a dummy sample. The air flow was regulated by plower with different air velocities, while the drying air temperature was adjusted by the digital thermostat. The actual drying tests were continued until the moisture content was in equilibrium with the temperature of the drying air. The samples weight and moisture content was recorded every $30 \mathrm{~min}$. At the end of the drying test, the moisture content of the dried samples was also determined as described by AOAC (1990).

\section{Experimental measurements:}

Determination of the nutrient, mineral and Phytochemical Components $\underline{\text { contents }}$

For the determination of nutrients (protein and vitamin C), the method of the Association of Official Analytical Chemist (AOAC, 1995) was used.

Calcium (Ca) in samples was determined by atomic absorption spectrophotometry after mineralization by hydrochloric acid (M.F.A‘,1982) and Potasium (K) were extracted from dried samples by acids before being determined with an atomic absorption spectrophotometer (M.F.A, 1982).

Moisture content (M.C. w.b. \%)

The moisture content in wet basis was measured for the tested moringa leaves by taking random samples $(50 \mathrm{~g})$ from leaves and drying it in electric oven at $105{ }^{\circ} \mathrm{C}$ for 24 hours to measure its moisture content 
according to AOAC (1990). The moisture content was calculated using to the following equation (Hassan, 2015):

$$
M=\frac{W_{i}-W_{f}}{W_{i}} \times 100
$$

Where:

$\mathrm{M}$ : Moisture content of leaves, $(\%)$.

$\mathrm{W}_{\mathrm{i}}$ : Initial mass of leaves $(\mathrm{g})$.

$\mathrm{W}_{\mathrm{f}}$ : Final mass of leaves $(\mathrm{g})$.

Moisture content wet base (Hashim et al. 2014):

$$
\mathrm{M}_{(\mathrm{w} . \mathrm{b})}=\frac{\mathrm{W}_{(\mathrm{w})}}{\mathrm{W}_{\mathrm{t}}} \times 100
$$

Where:

$\mathrm{M}_{(\mathrm{w} . \mathrm{b})}$ : Moisture content of plants (wet base), (\%).

$\mathrm{W}_{(\mathrm{w})}$ : Mass of water inleaves $(\mathrm{g})$.

$\mathrm{W}_{\mathrm{t}} \quad$ : Total mass of leaves, (water plus dry matter) (g).

Moisture content dry base (Fadhel et al. 2014):

$$
\mathrm{M}_{(\mathrm{d} . \mathrm{b})}=\frac{\mathrm{W}_{(\mathrm{w})}}{100-\mathrm{W}_{(\mathrm{w})}}
$$

Where:

$\mathrm{M}_{(\mathrm{d} . \mathrm{b})}$ : Moisture content of plants (dry base) $\left(\mathrm{g}_{\text {water }} / \mathrm{g}_{\text {solid }}\right)$.

$\mathrm{W}_{(\mathrm{w})}$ : Mass of water in the product (wet base) $\left(\mathrm{g}_{\text {water }} / \mathrm{g}_{\text {solid }}\right)$.

The drying rate (DR), moisture ratio (MR) ant evaporating rate (ER) of moringa leaves were calculated using the following equations (Premi, et al. 2010):

$$
\begin{gathered}
\mathrm{DR}=\frac{\mathrm{M}_{\mathrm{t}+\mathrm{dt}}-\mathrm{M}_{t}}{\mathrm{dt}} \\
\mathrm{ER}=\frac{\mathrm{W}_{\mathrm{t}+\mathrm{dt}}-\mathrm{W}_{\mathrm{t}}}{\mathrm{dt}} \\
\mathrm{MR}=\frac{\mathrm{M}_{\mathrm{t}}-\mathrm{M}_{\mathrm{e}}}{\mathrm{M}_{\mathrm{o}}-\mathrm{M}_{\mathrm{e}}}=\exp (-\mathrm{kt})
\end{gathered}
$$

Where:

$$
\begin{aligned}
& \text { DR : The drying rate, }\left(g_{w a t e r} / g_{\text {solid }} \cdot \min .\right) \\
& M_{t+d t}: \text { Moisture content at } t+d t\left(g_{w a t e r} / g_{\text {solid }}\right) . \\
& M_{t} \quad: \text { Moisture content at a specific time, }\left(g_{w a t e r} / g_{\text {solid }}\right) .
\end{aligned}
$$


ER : The evaporating rate, $\left(\mathrm{g}_{\text {water }} / \mathrm{min}\right.$.).

$\mathrm{W}_{\mathrm{t}+\mathrm{dt}}$ : Mass of leaves at $\mathrm{t}+\mathrm{dt},(\mathrm{g})$.

$\mathrm{W}_{\mathrm{t}} \quad$ : Mass of leaves at a specific time, $(\mathrm{g})$.

MR : The moisture ratio.

$\mathrm{M}_{\mathrm{e}} \quad$ : Equilibrium moisture content ( $\left.\mathrm{g}_{\mathrm{water}} / \mathrm{g}_{\text {solid }}\right)$.

$\mathrm{M}_{\mathrm{o}} \quad$ : The initial moisture content $\left(\mathrm{g}_{\mathrm{water}} / \mathrm{g}_{\text {solid }}\right)$.

$\mathrm{K} \quad$ : Drying constant $\left(\mathrm{min}^{-1}\right)$.

$\mathrm{t} \quad$ : Drying time (min.).

The average drying rate $\left(\mathrm{DR}_{\mathrm{ave}}\right)$ and average evaporating rate $\left(\mathrm{ER}_{\mathrm{ave}}\right)$ of moringa and neem leaves were calculated using the following equations

$$
\begin{aligned}
& \mathrm{DR}_{\mathrm{ave}}=\frac{\mathrm{M}_{\mathrm{i}}-\mathrm{M}_{\mathrm{f}}}{\mathrm{t}} \\
& \mathrm{ER}_{\mathrm{ave}}=\frac{\mathrm{W}_{\mathrm{i}}-\mathrm{W}_{\mathrm{f}}}{\mathrm{t}}
\end{aligned}
$$

Where:

$\mathrm{DR}_{\text {ave }}$ : Average drying rate, $(\% / \mathrm{h})$.

$\mathrm{M}_{\mathrm{i}} \quad$ : Initial moisture content (wet base), (\%).

$\mathrm{M}_{\mathrm{f}} \quad$ : Final moisture content (wet base), (\%).

$\mathrm{ER}_{\text {ave }}$ : Average evaborating rate, $(\mathrm{g} / \mathrm{h})$.

$\mathrm{W}_{\mathrm{i}} \quad$ : Initial mass of leaves $(\mathrm{g})$.

$\mathrm{W}_{\mathrm{f}}$ : Final mass of leaves $(\mathrm{g})$.

$\mathrm{t} \quad$ : Drying time (hours).

The drying ratio was calculated by the following equation

$$
\operatorname{Dr}=\frac{W_{W}}{W_{d}}
$$

Where:

Dr : Drying ratio.

$\mathrm{W}_{\mathrm{w}}$ : Mass of leaves after drying, $(\mathrm{g})$.

$\mathrm{W}_{\mathrm{d}}$ : Mass of leaves before drying, $(\mathrm{g})$.

\section{RESULTS AND DISCUSSION}

Effect of drying air temperatures and air velocities on moisture content of moringa leaves:

Fig. (2) show the effect of different air velocities on change of moisture content at different air temperatures of moringa leaves. As shown in the figures for moringa leaves, the moisture content decreased with the increase of air temperature and air velocity and consequently the drying 
time decreased. The obtained results demonstrated that for moringa the initial moisture content (wet base) was $86.7 \%$ and decreased to 10.75 , 9.85 and $9.35 \%$ within drying time 8,7 and 5.5 hours, respectively at air velocities $0.45,1.0$ and $1.5 \mathrm{~m} / \mathrm{sec}$., respectively at drying air temperature $60{ }^{\circ} \mathrm{C}$. Also, the moisture content decreased to 15,13 and $9.35 \%$ within drying time $10,7.5$ and 5.5 hours, respectively at drying air temperatures 40,50 and $60{ }^{\circ} \mathrm{C}$, respectively at air velocity $1.5 \mathrm{~m} / \mathrm{sec}$. This results are in agreement with the observations of earlier researcher (Ali, et al. 2014; premi, et al. 2010).

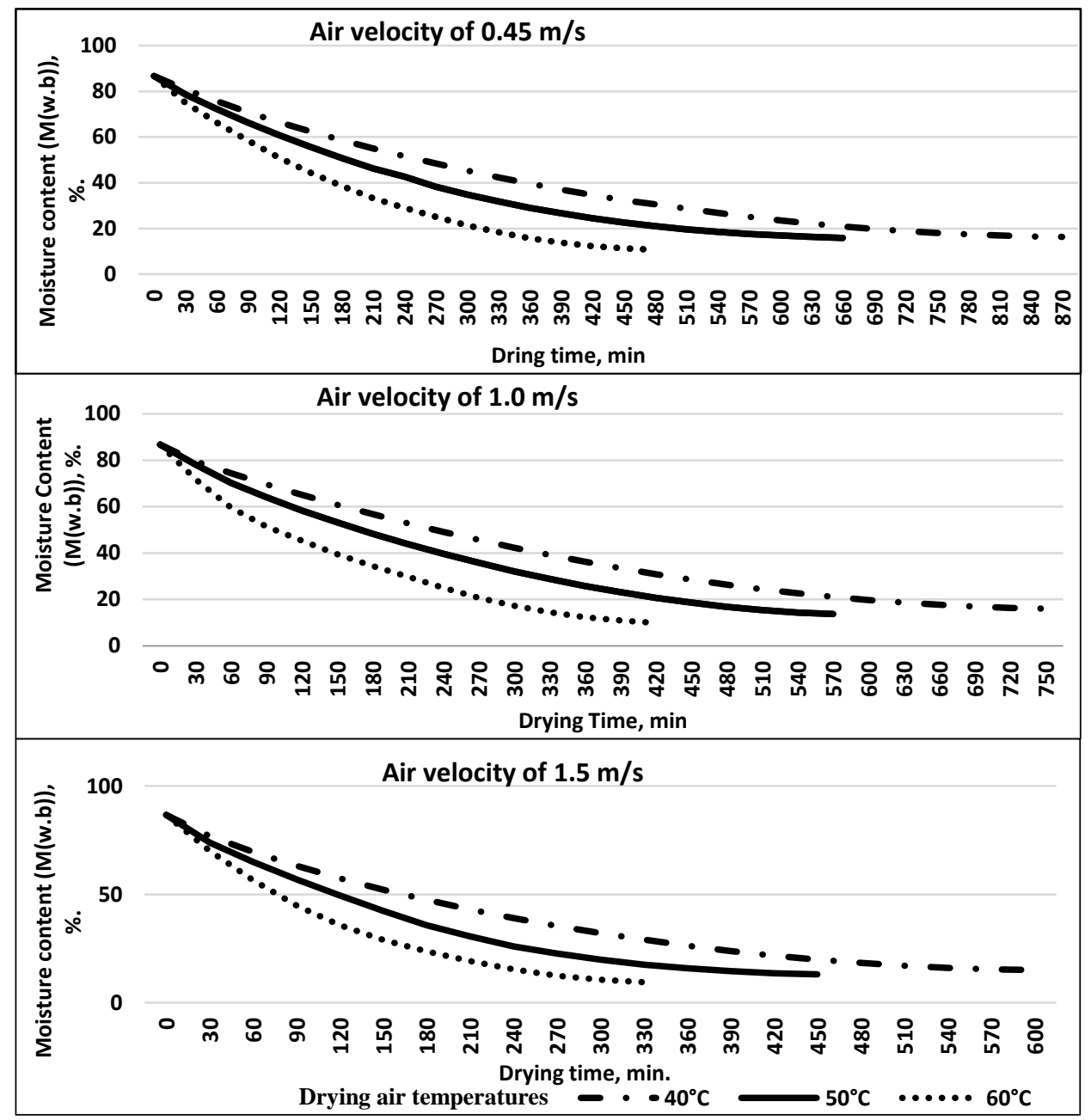

Fig. 2. Effect of drying air temperature and air velocity on moisture content for moringa leaves 


\section{Effect of drying air temperatures and air velocities on drying rate of}

\section{moringa leaves:}

Fig. (3) show the effect of different air velocities on change of drying rate at different air temperatures of moringa leaves. As shown in the figures at higher moisture content, the increase in temperature has more considerable effect on the drying rates as compared to lower temperatures, which is almost negligible towards the end. It was observed that the drying rate or moisture loss was faster at the beginning than that at the end. The reduction in the drying rate at the end of drying may be due to the reduction in moisture content. Thus, a higher drying air temperature produceda higher drying rate and consequently the moisture ratio decreased.

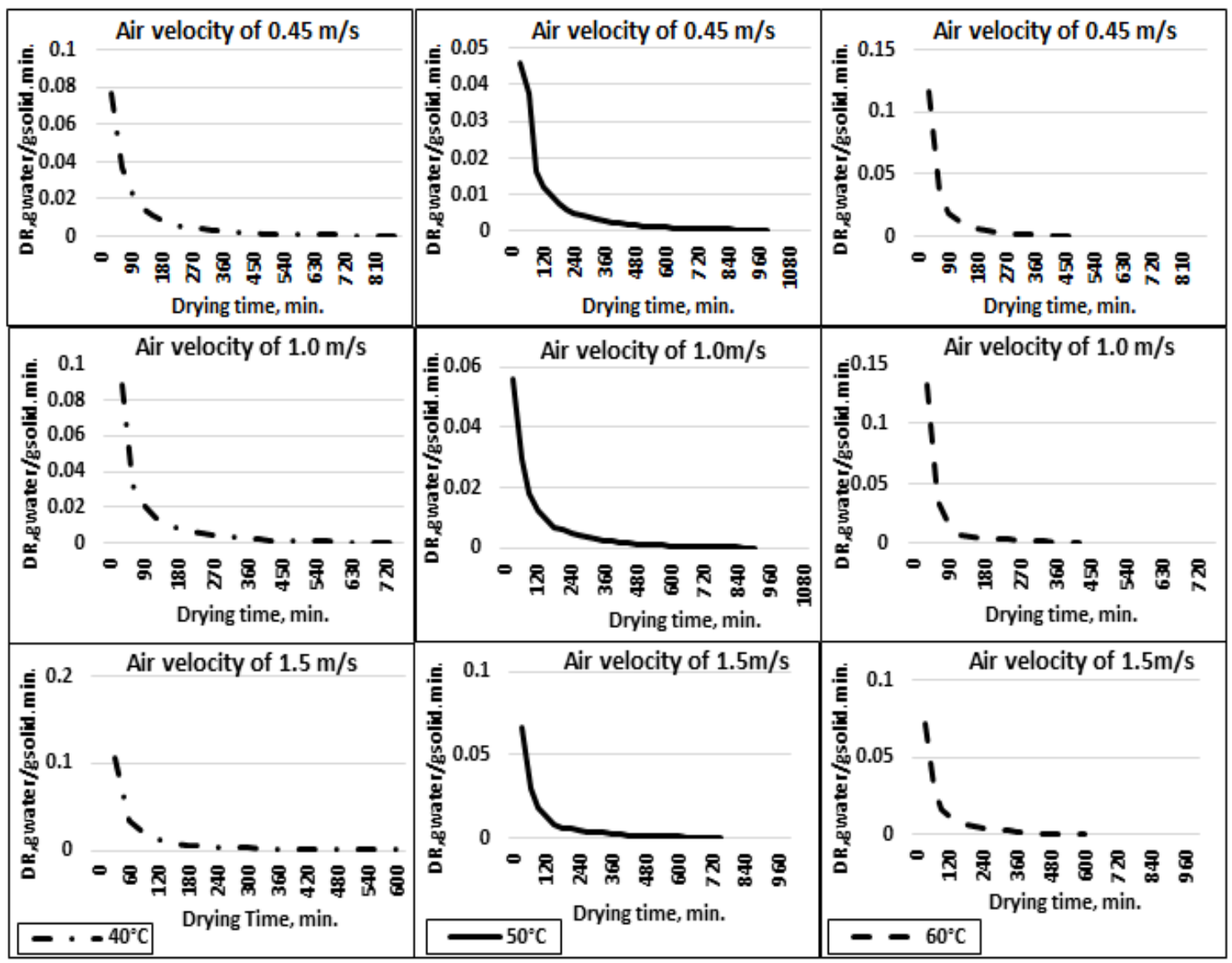

Fig. 3. Effect of drying air temperatures and air velocities on drying rate of moringa leaves 
Effect of drying air temperature and air velocity on drying time, drying ratio, average drying rate and average evaporating rate of moringa leaves

Table (1) show the effect of drying air temperature and air velocity on drying time, drying ratio, average drying rate and average evaporating rate of moringa leaves. Treatment, at drying air temperature $60{ }^{\circ} \mathrm{C}$ and air velocity $1.5 \mathrm{~m} / \mathrm{s}$. recorded the highest drying ratio 4.42:1, average drying rate $14.06 \% / \mathrm{h}$ and average evaporating rate $28.13 \mathrm{~g} / \mathrm{h}$ through drying time 5.5 hours which is the smallest drying time for moringa leaves.

Table 1: Effect of drying air temperature and air velocity on drying time, drying ratio, average drying rate and average evaporating rate of moringa leaves.

\begin{tabular}{|c|c|c|c|c|c|c|c|c|c|}
\hline $\begin{array}{c}\text { Drying air } \\
\text { temperature }\end{array}$ & \multicolumn{3}{|c|}{$40^{\circ} \mathrm{C}$} & \multicolumn{3}{c|}{$50^{\circ} \mathrm{C}$} & \multicolumn{3}{c|}{$60^{\circ} \mathrm{C}$} \\
\hline Air velocity & $\begin{array}{c}0.45 \\
\mathrm{~m} / \mathrm{s} .\end{array}$ & $\begin{array}{c}1.0 \\
\mathrm{~m} / \mathrm{s} .\end{array}$ & $\begin{array}{c}1.5 \\
\mathrm{~m} / \mathrm{s} .\end{array}$ & $\begin{array}{c}0.45 \\
\mathrm{~m} / \mathrm{s} .\end{array}$ & $\begin{array}{c}1.0 \\
\mathrm{~m} / \mathrm{s}\end{array}$ & $\begin{array}{c}1.5 \\
\mathrm{~m} / \mathrm{s}\end{array}$ & $\begin{array}{c}0.45 \\
\mathrm{~m} / \mathrm{s} .\end{array}$ & $\begin{array}{c}1.0 \\
\mathrm{~m} / \mathrm{s} .\end{array}$ & $\begin{array}{c}1.5 \\
\mathrm{~m} / \mathrm{s} .\end{array}$ \\
\hline $\begin{array}{c}\text { Initial M(w.b) } \\
(\%)\end{array}$ & 86.7 & 86.7 & 86.7 & 86.7 & 86.7 & 86.7 & 86.7 & 86.7 & 86.7 \\
\hline $\begin{array}{c}\text { Final M(w.b) } \\
(\%)\end{array}$ & 16.3 & 16.05 & 15 & 15.85 & 13.8 & 13 & 10.75 & 9.85 & 9.35 \\
\hline Time (h) & 14.5 & 12.5 & 10 & 11 & 9.5 & 7.5 & 8 & 7 & 5.5 \\
\hline $\begin{array}{c}\text { Drying ratio } \\
\text { Average DR } \\
(\% / h)\end{array}$ & $3.38: 1$ & $3.407: 1$ & $3.53: 1$ & $3.43: 1$ & $3.69: 1$ & $3.8: 1$ & $4.158: 1$ & $4.32: 1$ & $4.42: 1$ \\
\hline $\begin{array}{c}\text { Average ER } \\
\text { (g/h) }\end{array}$ & 9.71 & 11.264 & 14.34 & 12.88 & 15.35 & 19.65 & 18.99 & 21.96 & 28.13 \\
\hline
\end{tabular}

Effect of different drying air temperatures and air velocities on nutrient and mineral contents of moringa leaves:

Data in table (2) presents the influence of different drying air temperatures and different air velocities on nutrient and mineral contents for moringa leaves.

- Vitamin C and calcium were higher in drying air temperature of 40

${ }^{\circ} \mathrm{C}$ and air velocity of $0.45 \mathrm{~m} / \mathrm{s}$ and they were $233.488 \mathrm{mg} / 100 \mathrm{~g}$ and $0.934 \%$, respectively, while they were decreased by increasing drying air temperature and air velocity. 
- Drying air temperature of $60{ }^{\circ} \mathrm{C}$ and air velocity $1.5 \mathrm{~m} /$ sretained more protein $(11.965 \mathrm{mg} / 100 \mathrm{gm})$ and Potassium (1.112\%)in moringa leaves compared with low drying air temperature and air velocity.

Table (2): Effect of different drying air temperature and different air velocity on nutrient, mineral and Phytochemical Components contents for moringa leaves.

\begin{tabular}{|c|c|c|c|c|c|c|c|c|c|}
\hline Tempreture & \multicolumn{3}{|c|}{$40{ }^{\circ} \mathrm{C}$} & \multicolumn{3}{|c|}{$50{ }^{\circ} \mathrm{C}$} & \multicolumn{3}{|c|}{$60{ }^{\circ} \mathrm{C}$} \\
\hline Air velocity & $\begin{array}{c}\mathbf{0 . 4 5} \\
\mathrm{m} / \mathrm{sec}\end{array}$ & $\begin{array}{c}1.0 \\
\mathrm{~m} / \mathrm{sec}\end{array}$ & $\begin{array}{c}1.5 \\
\mathrm{~m} / \mathrm{sec}\end{array}$ & $\begin{array}{c}0.45 \\
\mathrm{~m} / \mathrm{sec}\end{array}$ & $\begin{array}{c}1.0 \\
\mathrm{~m} / \mathrm{sec}\end{array}$ & $\begin{array}{c}1.5 \\
\mathrm{~m} / \mathrm{sec}\end{array}$ & $\begin{array}{c}0.45 \\
\mathrm{~m} / \mathrm{sec}\end{array}$ & $\begin{array}{c}1.0 \\
\mathrm{~m} / \mathrm{sec}\end{array}$ & $\begin{array}{c}1.5 \\
\mathrm{~m} / \mathrm{sec}\end{array}$ \\
\hline $\begin{array}{c}\text { Vitamin C } \\
(\mathrm{mm} \\
\mathrm{gm} / 100 \mathrm{gm})\end{array}$ & 233.488 & 230.56 & 227.94 & 197.44 & 195.26 & 192.018 & 173.5 & 167.22 & 163.462 \\
\hline $\begin{array}{l}\text { Protin }(\mathbf{m m} \\
\text { gm } / 100 \mathrm{gm})\end{array}$ & 6.965 & 6.722 & 6.631 & 7.426 & 7.126 & 7.031 & 11.431 & 11.612 & 11.965 \\
\hline $\begin{array}{l}\text { Potassium } \\
(\mathrm{K})(\%)\end{array}$ & 0.962 & 0.946 & 0.918 & 1.055 & 1.032 & 1.016 & 1.101 & 1.106 & 1.112 \\
\hline $\begin{array}{l}\text { Calcum } \\
\text { (ca) }(\%)\end{array}$ & 0.934 & 0.921 & 0.915 & 0.889 & 0.881 & 0.877 & 0.858 & 0.849 & 0.841 \\
\hline
\end{tabular}

\section{CONCLUSION}

Drying characteristics and quality changes of moringa leaves were examined at three different temperatures and three different air velocities in this study. Moisture content and drying time decreased considerably as temperature and air velocity increase. The drying rate of moringa leaves at all temperatures was occurred in falling rate and constant rate period was absent. the quality tests of dried moringa leaves showed that, at air temperature $60^{\circ} \mathrm{C}$ with air velocity $1.5 \mathrm{~m} / \mathrm{s}$ showed the best quality in terms of higher retention of Protein and Potassium, while at air temperature $40^{\circ} \mathrm{C}$ with air velocity $0.45 \mathrm{~m} / \mathrm{s}$ showed the best quality in terms of higher retention of vitamin $\mathrm{C}$ and calcium.

\section{REFERENCES}

Abdel-Galil, H.S. and A.A. El-Nakib. (2008). Effect of natural convection solar drying on quality of peppermint. The 15th Annual Conference of the Misr Society of Ag. Eng.

Ali, M. A., Yusof, Y. A., Chin, N. L., Ibrahim, S. M. A. and Basra (2014). Drying kinetics and colour analysis of moringa oleifera leaves. $2^{\text {nd }}$ International Conference on Agricultural and Food 
Engineering, Agriculture and Agricultural Science Procedia 2: 394 -400 .

Amer, B.M.A. (2012). Determination of optimum conditions for thinlayer drying of lemon balm leaves (Melissa Officinalis L.). Misr J. Of Ag. Eng., 29 (1): 359-376.

AOAC, (1970). Official methods of analysis. Association of Official Analytical Chemists, Washington D.C. $11^{\mathrm{ed}}$.

AOAC, Association of Official Analytical Chemists (1990). Official Methods of Analysis. 15th ed. Association of Official Analytical Chemists, Washington D.C., U.S.A.

AOAC, (1995). Official methods of analysis (16th Ed.). Arlington VA, USA: Association of Official Analytical Chemists.

Arafa, G. K. (2007). Optimum drying conditions for thin-layer drying of sweet basil. Misr J. Ag. Eng., 24(3):540-556.

Djeridane, A., Yousfi, M., Nadjemi, B., Boutassouna, D., Stocker, P. and Vidal, N. (2006). Antioxidant activity of some Algerian medicinal plants extracts containing phenolic compounds. Food chem. 97 (4): 654-660.

Fadhel, A., Kooli, S., Farhat, A. and Belghith, A. (2014). Experimental study of the drying of hot red pepper in the open air, under green house and in a solar drier. International Journal of Renewable Energy \& Biofuels.

Hashim, N., Daniel, O. and Rahamana, E. (2014). A preliminary study: kinetic model of drying process of pumpkins (Cucurbita Moschata) in a convective hot air dryer. Agriculture and Agricultural Science Procedia, 2: 345 - 352.

Hassan, M.M.A. (2015). Solar drying performance study of some crops (mint, okra and grapes) I- assessing the drying rates. Misr J. Of Ag. Eng., 32(1):205-222.

Hossain, M. A., Al-Toubi, W. A. S., Weli, A. M., Al-Riyami, Q. A. and Al-Sabahi, J. N. (2013). Identification and characterization of chemical compounds indifferent crude extracts from leaves of omani neem. Journal of Taibah University for Science 7: 181-188.

Kassem, A. M., I. E. El-Batawi and Mahassen M. S. (2006). Effect of solar energy and other drying methods on quality of some medicinal plants. The $14^{\text {th }}$ Annual Conference of the Misr Society of Ag. Eng., 22 November :766:782. 
Mujumdar, A.S. (1995) "Handbook of industrial drying" 2 nd. Ed. revised and expanded. 2:150-174.

M.F.A. (1982). Methods of food analysis. NiponShokuhin Kogyo Gakaishi, Tokyo.

Ozguven, M. and Tansi, S. (1999). Determination of yield and quality in marjoram as influenced by development periods. Turkish-J of Agr. and Forestry. 23(1): 11-17.

Öztekin, S. and Martinov, M. (2007). Medicinal and aromatic crops harvesting, drying and Processing. Haworth Food and Agricultural Products Press $^{\mathrm{tm}}$, An Imprint of the Haworth Press, Inc., 10 Alice Street, Binghamton, New York 13904-1580 USA.

Premi, M.; Sharma, H.K.; Sarkar, B.C. and Singh, C. (2010). Kinetics of drumstick leaves (Moringa oleifera) during convective drying. African Journal of Plant Science, 4 (10): 391-400.

Shokr, A. Z., E. A., Abdel Ghaffar, M. A., Rashwan and S. S., Shaaban (2011). Development of the drying characteristic coefficients of dried marigold plants by using of an electrical laboratory drying system. Misr J. Of Ag. Eng., 28 (1): 181-200.

Vinoth, B., Manivasagaperumal, R. and Rajaravindran, M. (2012). Phytochemical analysis and antibacterial activity of azadirachta indica ajuss. International Journal of Research in Plant Science, 2(3): 50-55.

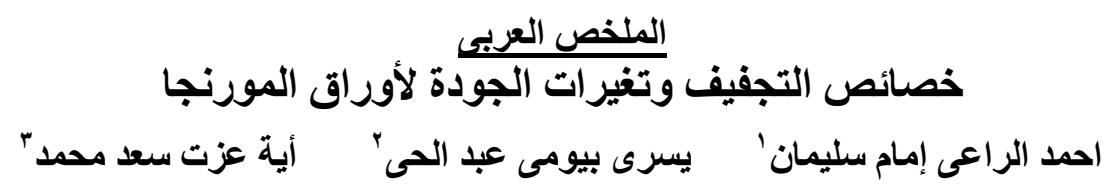

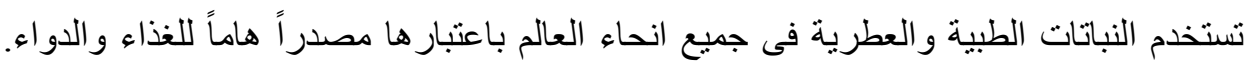

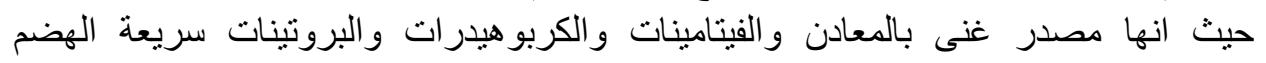

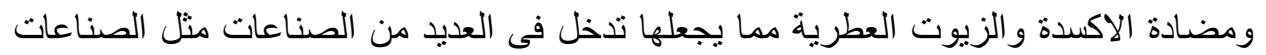

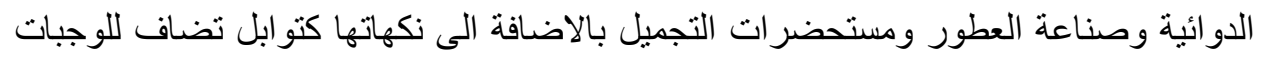

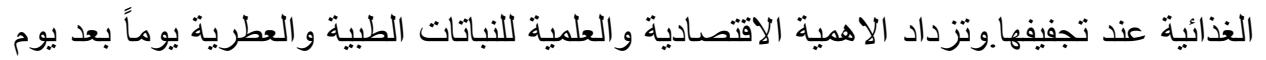

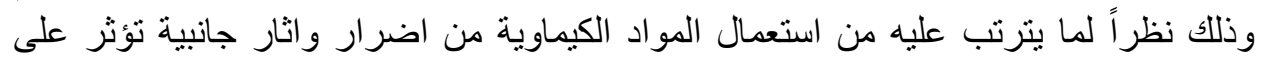

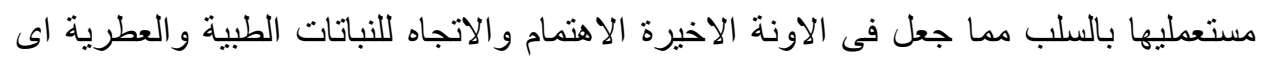
الرجوع الى المصادر الطبيعية.

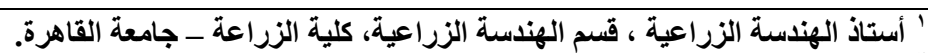

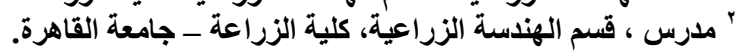
" طالبة دراسات عليا ، قسم الهنسة الزراعية، كلية الزراعة - جامعة القاهرة. 
ومن النباتات الطبية والعطرية التى لها العديد من الفؤاد الطبية نبات المورنجا اوليفرا و الذى الذى الفي تعتبر اور اقه غنية بالفيتامينات و العديد من العناصر الغذائية والبيتاكاروتينات و البروتين ويستخدم كمكمل غذائى لمصابى نقص المناعة فى بعض بلد بلدان افريقيا.

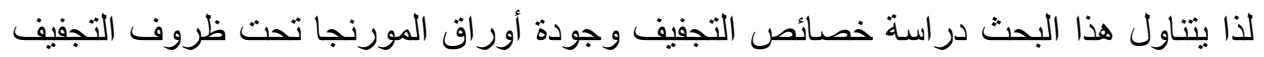
المختلفة من درجات حرارة وسرعات هواء باستخدام مجفف معملى لتجفيف أوراق المورنجا

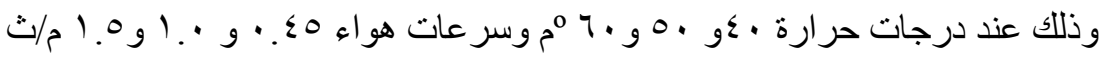

\section{وقد أظهرث النتائج مايلى:-}

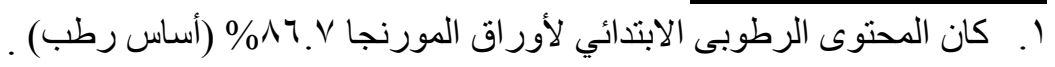

r. . عند استخدام المجفف المعملى كنموذج للتجفيف الصناعى تبين أن اختلاف درجات الحرارة

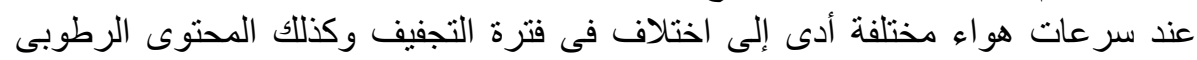

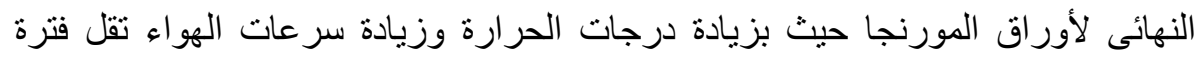

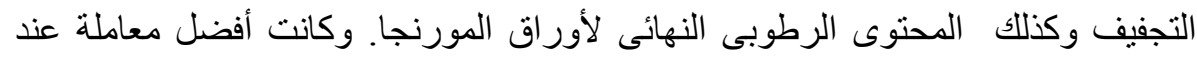

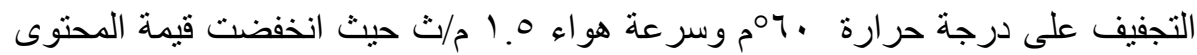

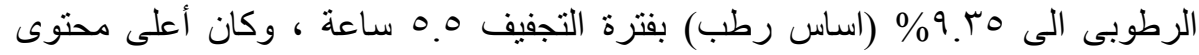

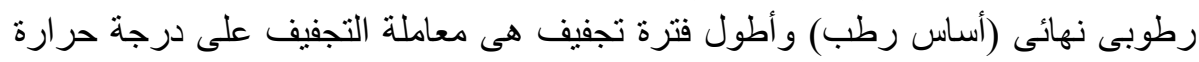

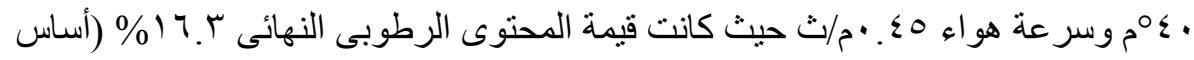
رطب) بفترة تجفيف 0. 1 أساعة.

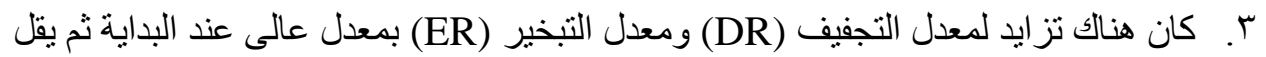

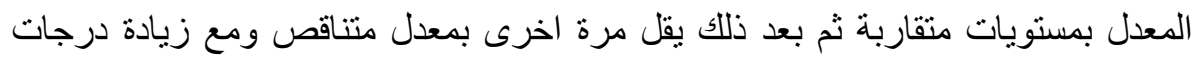

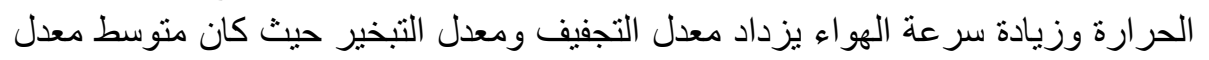

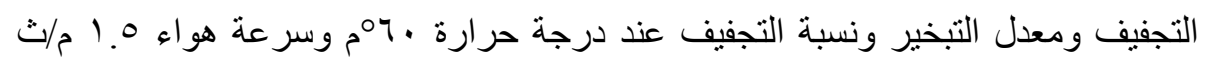

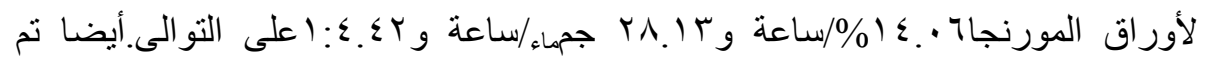

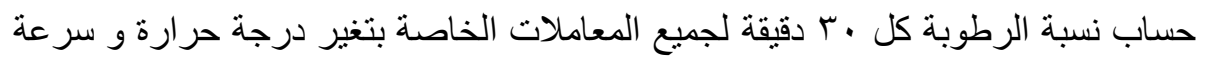

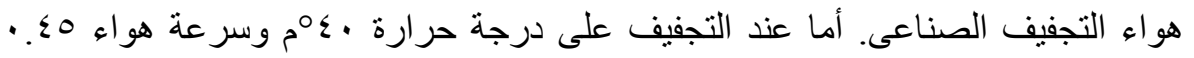
م/ث فقد كان متوسط معدل التجفيف ومتوسط معدل التبخير ونسبة التجفيف لاوراق

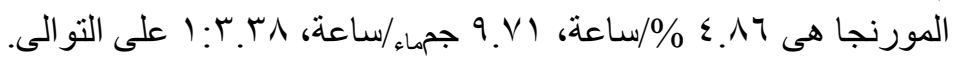

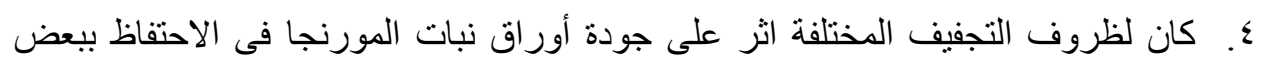

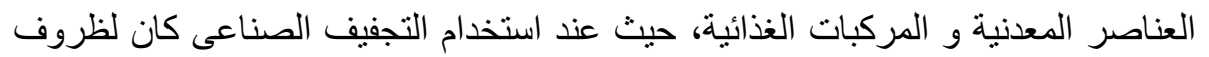
التجفيف المختلفة من اختلاف درجات الحرارة وسرعات الهواء تأثثر على عناصر الجودة الجيرة

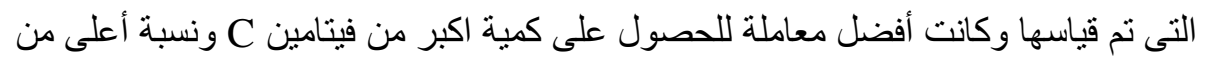

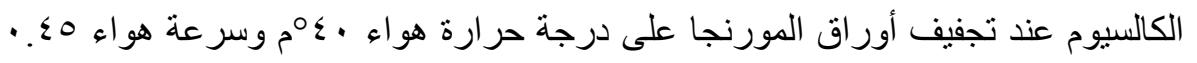

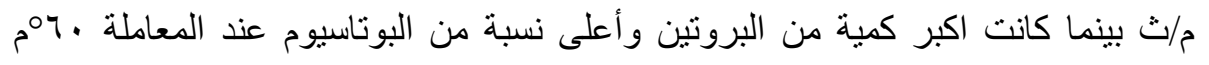
وسر عة هو اء م. 1 ماتث. اكبر. 